\section{Is Tocilizumab an Effective Option for Treatment of Refractory Uveitis Associated with Juvenile Idiopathic Arthritis?}

To the Editor:

Anti-interleukin 6 receptor (anti-IL-6R) antibodies have been effective in experimental models of autoimmune arthritis, encephalomyelitis, and also uveitis ${ }^{1,2}$. Tocilizumab (TCZ; RoActemra ${ }^{\circledR}$, Hoffmann-La Roche, Basel, Switzerland), a fully humanized anti-IL-6R antibody, has been approved for the treatment of rheumatoid arthritis. Efficacy has also been shown for systemic-onset juvenile idiopathic arthritis (JIA) ${ }^{3}$ and vasculitis ${ }^{4}$. To date, however, no reports have appeared concerning its efficacy in JIA-associated uveitis.

In about one-third of JIA patients with uveitis, eye inflammation runs a severe course and vision-threatening complications develop, and immunosuppressive treatment is required ${ }^{5}$. Because some patients do not respond properly to the widely used disease-modifying antirheumatic drugs (DMARD), including tumor necrosis factor- $\alpha$ (TNF- $\alpha$ ) inhibitors, there is a significant need for alternative treatment options. We describe our initial experience with TCZ for treatment of JIA-associated uveitis at a tertiary uveitis and pediatric rheumatology referral center.

Three adult patients (mean age 18.3 yrs) with JIA-associated chronic anterior uveitis (mean duration 8 yrs, range 4-13) with insidious onset of flare and the presence of vision-threatening complications (Table 1) were treated with intravenous TCZ $8 \mathrm{mg} / \mathrm{kg}$ body weight at 4-weekly intervals ${ }^{6}$. Written informed consent was obtained from patients for off-label use of TCZ. In all patients the disease had been refractory to high dosages of topical corticosteroids and previous systemic corticosteroid treatment and DMARD, including at least 1 TNF- $\alpha$ inhibitor; all were used at conventional medication doses (Table 2). Within the followup period under TCZ treatment (mean followup 9 mo, range 6-12), inactivity of the uveitis (< 0.5 anterior chamber cells ${ }^{7}$ ) was achieved in Patients 2 and 3 for all eyes with previous activity (Table 2). Uveitis continued in the other patient, requiring a further increase in the dosage of topical steroids. Mean best-corrected visual acuity improved by 1 line in Patient 2 and by 4 lines in Patient 3 during the subsequent followup period under TCZ. No patient developed additional eye complications during the intermediate-term of TCZ treatment; no adverse events were observed related to TCZ. In all 3 patients, arthritis that had been active before TCZ treatment improved during followup ${ }^{8}$. Adalimumab and abatacept were withdrawn before initiating the TCZ treatment. Otherwise, steroids or immunosuppression treatment was not spared in any significant way.

IL-6 is a pleiotropic, proinflammatory cytokine mainly produced by T cells and monocytes/macrophages, inducing proliferation and differentiation of T cells as well as the terminal differentiation of B cells ${ }^{9}$. IL-6 is a key agent generating Th17 cells while inhibiting regulatory $\mathrm{T}$ cell generation ${ }^{10}$. Increased serum levels of IL-6 have been found in several systemic autoimmune diseases and also in diverse uveitis entities ${ }^{11}$. In an animal model, IL-6-deficient mice showed an impaired Th17 response and a lower inflammation score in experimental autoimmune uveitis ${ }^{1}$. In our case series, TCZ treatment achieved suppression of uveitis in 2 of 3 patients in whom disease had been refractory to previous DMARD, including at least 1 TNF- $\alpha$ inhibitor. In our cases, all medication was used at conventional doses. Whether further dose escalation (e.g., adalimumab at once-weekly intervals) would have been more effective is unclear.

TCZ may represent a treatment option for otherwise refractory JIA-associated uveitis. Further prospective studies are needed to evaluate the efficacy of this new drug in comparison to other biologicals.

CHRISTOPH TAPPEINER, MD, FEBO, Department of Ophthalmology, Inselspital, University of Bern, Bern, Switzerland; CARSTEN HEINZ, MD, FEBO, Department of Ophthalmology, St. Franziskus Hospital, Münster, and University of Essen, Essen, Germany; GERD GANSER, MD, Department of Pediatric Rheumatology, St. Josef Stift, Sendenhorst,

Table 1. Adult patients with juvenile idiopathic arthritis (JIA)-associated uveitis were treated with tocilizumab when refractory to topical corticosteroids and systemic immunosuppression.

\begin{tabular}{ccccccccc}
\hline Patient & Age*/sex & $\begin{array}{c}\text { ILAR } \\
\text { Classification }\end{array}$ & HLA-B27/ANA/RF & $\begin{array}{c}\text { JIA Diagnosis Uveitis Diagnosis } \\
\text { at Age, yrs }\end{array}$ & $\begin{array}{c}\text { Uveitis } \\
\text { at Age, yrs }\end{array}$ & $\begin{array}{c}\text { Involved } \\
\text { Eyes }\end{array}$ & Complications \\
\hline 1 & $18 \mathrm{M}$ & Oligoarthritis, ext. & Neg/pos/neg & 4 & 5 & Anterior & Both & Cataract, synechiae, glaucoma \\
2 & $18 \mathrm{~F}$ & Polyarthritis & Neg/pos/neg & 11 & 11 & Anterior & $\begin{array}{c}\text { Both } \\
\text { Left }\end{array}$ & $\begin{array}{c}\text { Cataract, synechiae } \\
\text { Cataract, synechiae, macular } \\
\text { edema, glaucoma }\end{array}$ \\
\hline
\end{tabular}

* At time of starting tocilizumab therapy. ** Standardization of Uveitis Nomenclature classification ${ }^{7}$. ANA: antinuclear antigen; RF: rheumatoid factor; ILAR: International League of Associations for Rheumatology.

Table 2. Response to treatment in adult patients with juvenile idiopathic arthritis (JIA)-associated uveitis treated with tocilizumab (TCZ) when refractory to topical corticosteroids and systemic immunosuppression. Dosages were within generally used ranges, e.g., for methotrexate (MTX) $15 \mathrm{mg} / \mathrm{m}^{2}$, azathioprine (AZA) $2 \mathrm{mg} / \mathrm{kg}$ body weight, adalimumab (ADA) $40 \mathrm{mg}$ biweekly, etanercept (ETA) $0.8 \mathrm{mg} / \mathrm{kg}$ body weight weekly, abatacept (ABA) $10 \mathrm{mg} / \mathrm{kg}$ body weight monthly.

\begin{tabular}{|c|c|c|c|c|c|c|c|c|}
\hline Patien & $\begin{array}{c}\text { Treatment } \\
\text { Prior to } \\
\text { TCZ }\end{array}$ & $\begin{array}{c}\text { Uveitis } \\
\text { Activity }^{\dagger} \\
\text { After TCZ }\end{array}$ & $\begin{array}{l}\text { Months } \\
\text { Until } \\
\text { Inactive }\end{array}$ & $\begin{array}{c}\text { Sparing of } \\
\text { Other } \\
\text { Immunosuppressives } \\
\text { After TCZ** }\end{array}$ & $\begin{array}{c}\text { Steroid } \\
\text { Eye Drops } \\
\text { Before/ } \\
\text { After TCZ } \\
=\text { times daily }\end{array}$ & $\begin{array}{c}\text { Uveitis } \\
\text { Recurrence } \\
\text { After TCZ } \\
\text { (followup, mo) }\end{array}$ & $\begin{array}{c}\text { Arthritis } \\
\text { Activity }{ }^{\dagger \dagger} \\
\text { Prior to } \\
\text { TCZ }\end{array}$ & $\begin{array}{c}\text { Arthritis } \\
\text { Activity }{ }^{\dagger \dagger} \\
\text { After TCZ }\end{array}$ \\
\hline 1 & PRED*, MTX*, ETA, ADA, ABA* & Active & - & No & $5 / 7$ & Ongoing; 8 & Yes & Improved \\
\hline 2 & PRED*, MTX*, ETA, ADA* & Inactive & 1 & No & $4 / 2$ & No; 12 & Yes & Improved \\
\hline
\end{tabular}

$\dagger$ Uveitis activity determined according to SUN criteria ${ }^{7}{ }^{\dagger}$ Arthritis activity determined by PedACR30/50/70 criteria ${ }^{8}$. Pred: prednisolone; SUN: Standardization of Uveitis Nomenclature. 
Germany; ARND HEILIGENHAUS, MD, FEBO, Department of Ophthalmology, St. Franziskus Hospital, Münster, and University of Essen, Essen, Germany. Address correspondence to Dr. A. Heiligenhaus, Department of Ophthalmology and Ophtha Lab, St. Franziskus Hospital, Hohenzollernring 74, 48145 Münster, Germany.

E-mail: arnd.heiligenhaus@uveitis-zentrum.de

\section{REFERENCES}

1. Yoshimura T, Sonoda K-H, Ohguro N, Ohsugi Y, Ishibashi T, Cua DJ, et al. Involvement of Th17 cells and the effect of anti-IL-6 therapy in autoimmune uveitis. Rheumatology 2009;48:347-54.

2. Ishihara K, Hirano T. IL-6 in autoimmune disease and chronic inflammatory proliferative disease. Cytokine Growth Factor Rev 2002;13:357-68.

3. Mircic M, Kavanaugh A. Inhibition of IL6 in rheumatoid arthritis and juvenile idiopathic arthritis. Exp Cell Res 2011;317:1286-92.

4. Seitz M, Reichenbach S, Bonel HM, Adler S, Wermelinger F, Villiger PM. Rapid induction of remission in large vessel vasculitis by IL-6 blockade. A case series. Swiss Med Wkly 2011;141:w13156.

5. Edelsten C, Lee V, Bentley CR, Kanski JJ, Graham EM. An evaluation of baseline risk factors predicting severity in juvenile idiopathic arthritis associated uveitis and other chronic anterior uveitis in early childhood. Br J Ophthalmol 2002;86:51-6.
6. Imagawa T, Yokota S, Mori M, Miyamae T, Takei S, Imanaka H, et al. Safety and efficacy of tocilizumab, an anti-IL-6-receptor monoclonal antibody, in patients with polyarticular-course juvenile idiopathic arthritis. Mod Rheumatol 2012;22:109-15.

7. Jabs DA, Nussenblatt RB, Rosenbaum JT, Standardization of Uveitis Nomenclature (SUN) Working Group. Standardization of uveitis nomenclature for reporting clinical data. Results of the First International Workshop. Am J Ophthalmol 2005;140:509-16.

8. Ruperto N, Ravelli A, Falcini F, Lepore L, De Sanctis R, Zulian F, et al. Performance of the preliminary definition of improvement in juvenile chronic arthritis patients treated with methotrexate. Italian Pediatric Rheumatology Study Group. Ann Rheum Dis 1998;57:38-41.

9. Mima T, Nishimoto N. Clinical value of blocking IL-6 receptor. Curr Opin Rheumatol 2009;21:224-30.

10. Bettelli E, Carrier Y, Gao W, Korn T, Strom TB, Oukka M, et al. Reciprocal developmental pathways for the generation of pathogenic effector TH17 and regulatory T cells. Nature 2006;441:235-8

11. Nishimoto N, Kishimoto T. Interleukin 6: From bench to bedside. Nat Clin Pract Rheumatol 2006;2:619-26.

J Rheumatol 2012;39:6; doi:10.3899/jrheum.120010 